\title{
Annealing of a ferritic stainless steel 409 stabilized with titanium and zirconium additions ${ }^{(\bullet)}$
}

\author{
J.L. Cavazos*, M.P. Guerrero-Mata* and P. Zambrano*
}

\begin{abstract}
A ferritic stainless steel 409 stabilized with titanium and zirconium was subject to thermomechanical processing. It was heated at $1210^{\circ} \mathrm{C}$ for one hour, followed by a $75 \%$ hot reduction in three passes, this rolling schedule ended at $980^{\circ} \mathrm{C}$. Samples were cooled to $600^{\circ} \mathrm{C}$ by water spraying followed by air-cooling. The alloy was pickled, and was reduced $80 \%$ by cold rolling. The alloy was annealed at different temperatures for $105 \mathrm{~s}$. Additional annealing treatments were carried out at temperatures of 800,850 and $900{ }^{\circ} \mathrm{C}$ for different times. Mechanical testing and texture were made to corroborate the degree of annealing and formability. Mechanical properties and Texture analyses showed that the alloy annealed at $850^{\circ} \mathrm{C}$ for 14 min was both completely recrystallized and a very good formability.
\end{abstract}

\section{Recocido de una aleación de acero inoxidable ferrítico 409 estabilizado con adiciones de titanio y zirconio}

\begin{abstract}
Resumen
Un acero inoxidable ferrítico 409 estabilizado con titanio y zirconio fue sujeto a procesos termomecánicos. El acero fue calentado a $1210{ }^{\circ} \mathrm{C}$ durante una hora, seguido por un laminado en caliente del $75 \%$ en tres pases, el proceso terminó a los $980^{\circ} \mathrm{C}$. Las muestras fueron enfriadas hasta $600^{\circ} \mathrm{C}$ por agua atomizada seguido de enfriamiento al aire. La aleación fue decapada y laminada en frío un $80 \%$. Posteriormente de desarrollaron tratamientos térmicos de recocido a diferentes temperaturas por un tiempo de $105 \mathrm{~s}$. Adicionalmente se desarrollaron tratamientos de recocido a temperaturas de 800,850 y $900^{\circ} \mathrm{C}$ a diferentes tiempos. Pruebas mecánicas y textura fueron realizadas para corroborar el grado de recocido y su formalidad. El análisis de las propiedades mecánicas y la Textura mostraron que la aleación recocida a $850^{\circ} \mathrm{C}$ por $14 \mathrm{~min}(840 \mathrm{~s}$ ) fue completamente recristalizada obteniendo la mejor formabilidad.
\end{abstract}

Palabras clave

Acero inoxidable ferrítico; Estabilizado; Textura; Zr.

\section{INTRODUCTION}

Ferritic stainless steels are alloys of iron and chromium containing $15-30 \% \mathrm{Cr}$ with additions of Mo, Mn, $\mathrm{Si}, \mathrm{Al}, \mathrm{Nb}, \mathrm{Ti}$, and essentially free from nickel. Table I shows typical compositions of these alloys, particularly one of the most used for catalytic exhaust systems.

The exhaust systems of practically all passenger cars produced in the United States are made from stainless steels. About $23 \mathrm{~kg}$ (50.6 lbs) of stainless steels are currently used per vehicle. This level translates to an annual consumption of approximately 400,000 tons of stainless steels in a market of 15 million vehicles per year ${ }^{[1]}$.
Due to increasing restrictions to minimize air pollution, the automotive industry has been requested to guarantee a 10 years lifetime for exhaust systems. Therefore, it is necessary to design new alloys with improved formability and corrosion resistance.

The main problem with stainless steels is sensitization, which is caused by the formation of chromium carbides or nitrides at grain boundaries. This phenomenon leaves a depleted chromium zone around the precipites that makes the steel susceptible to intergranular corrosion. Addition of elements that scavenge carbon and nitrogen rather than chromium solves this problem. The elements that have been found to be most useful are titanium and niobium. When sensitization is

\footnotetext{
(•) Trabajo recibido el día 12 de enero de 2010 y aceptado en su forma final del día 5 de agosto de 2010.

* Universidad Autónoma de Nuevo León, Facultad de Ingeniería Mecánica y Eléctrica, Avda. Universidad S/N, Cd. Universitaria, San Nicolás de los Garza, Nuevo León, 66450 MEXICO. E-mail: jose.cavazosgc@uanl.edu.mx.
} 
controlled, the alloy is fully stabilized. Addition of titanium and niobium increase the corrosion resistance ${ }^{[2]}$, improves formability ${ }^{[3 \text { and } 4]}$ and allows weld toughness in the produced steel ${ }^{[5]}$.

A ferritic stainless steel with zirconium and titanium additions was designed to stabilize the alloy; good corrosion resistance and very good formability by thermomecanical processing was obtained ${ }^{[6]}$.

The term texture is used in reference to the distribution of crystal orientations in a polycrystalline aggregate $^{[7 \text { and } 8]}$. In the usual sense, it is a synonymous to a preferred orientation, in which the distribution of crystal orientations is not random. A polycrystalline aggregate with a preferred orientation is anisotropic in nature ${ }^{[9]}$, i.e., it shows different properties in different directions. This dependence of properties on direction could be either beneficial or detrimental, depending upon the intended use of the material. Also, a texture that is beneficial for a particular application could be detrimental in another one. Materials that are designed to be formed are processed to achieve a high value of $r_{m}$ (normal anisotropy); the ideal crystallographic orientation to maximize $r_{m}$ in bcc metals would be a sheet texture with $<111>$ in the direction normal to the sheet and $\{111\}$ oriented randomly in the plane of the sheet ${ }^{[10]}$. The correct texture gives the proper orientation of slip systems so that the strength in the normal direction (ND) is greater that than in the plane of the sheet. To improve the properties of ferritic stainless steels, one of the factors is to create a desirable texture after cold rolling and annealing for improving deep drawability. That is to develop a strong texture $<111>/ / \mathrm{ND}$.

The objective of this work is to determinate the adequate temperature and time to obtain a full annealing in a ferritic stainless steel 409 with zirconium and titanium additions to improve the formability. Full annealing will be related by texture analyses and mechanical testing.

\section{EXPERIMENTAL PROCEDURE}

The chemical composition of the alloy was obtained from laboratory ingots; the results are presented along with the nominal alloy values in table I. The ingots were sectioned into pieces of $25.4 \mathrm{~mm}$ (thick) by $76.2 \mathrm{~mm}$ (wide) by $101.6 \mathrm{~mm}$ (long). A thermocouple was placed into the center of each sample. The specimens were heated at $1210^{\circ} \mathrm{C}$ for one hour, followed by a $75 \%$ reduction in three passes ( 25.4 to $6.35 \mathrm{~cm})$. The temperature at the exit of the first pass was $1160^{\circ} \mathrm{C}$; at the exit the second pass was 1075 ${ }^{\circ} \mathrm{C}$, and at the exit of the third pass was $980^{\circ} \mathrm{C}$. At this point the alloys were cooled to $600^{\circ} \mathrm{C}$ by water spray followed by air-cooling, this schedule was for avoiding martensite formation, no martensite was found after hot rolling. The alloy was pickled in a solution of $\mathrm{HCl}$ in water to remove the oxide layer. The material was then reduced $80 \%$ by cold rolling in four passes $(6.1 \mathrm{~mm}$ to $1.12 \mathrm{~mm})$. Table II shows the rolling schedules.

The samples were annealed at different temperatures in the range from 300 to $900{ }^{\circ} \mathrm{C}$ with intervals of $100^{\circ} \mathrm{C}$ during $105 \mathrm{~s}$. This procedure is the conventional treatment in a continuous annealing line. Additional heat treatments were made at temperatures of 800,850 and $900^{\circ} \mathrm{C}$ at different times (3.5, 7 and $14 \mathrm{~min})$. The temperatures were measured in the samples using a thermocouple. Microhardness was measured using a load of $500 \mathrm{~g}$ for $15 \mathrm{~s}$.

Quantitative metallographic analyses were performed on specimens cut from cold rolled and annealed samples using image analyzer system, to get the average grain size and aspect ratio. A minimum of 300 grains were measured for each specimen to obtain a true picture of the bulk sample and obtain a proper statistical distribution of the grains.

Texture on a local basis was obtained in a scanning electronic microscopy adapted with the TSL

Table I. Chemical Composition for alloy 409 (ASTM 240) ${ }^{[17]}$ and the one selected for this work

Tabla I. Composición Química de la aleación 409 (ASTM 240) ${ }^{[17]}$ y la seleccionada para este trabajo

\begin{tabular}{|c|c|c|c|c|c|c|c|c|c|c|c|}
\hline & C & $\mathbf{N}$ & Mn & $\mathbf{P}$ & $S$ & $\mathbf{S i}$ & $\mathrm{Cr}$ & $\mathrm{Ni}$ & $\mathrm{Ti}$ & $\mathrm{Zr}$ & $\mathrm{Ta}$ \\
\hline Nominal & $\begin{array}{l}0.08 \\
\max .\end{array}$ & - & $\begin{array}{l}1.00 \\
\max .\end{array}$ & $\begin{array}{l}0.045 \\
\max .\end{array}$ & $\begin{array}{l}0.030 \\
\max .\end{array}$ & $\begin{array}{l}1.00 \\
\text { max. }\end{array}$ & $10.5-11.75$ & $\begin{array}{l}0.50 \\
\max .\end{array}$ & $\begin{array}{c}6 x \mathrm{Cmin} \text {. } \\
0.75 \text { max. }\end{array}$ & - & - \\
\hline This Work & 0.021 & 0.02 & 0.13 & - & - & 0.39 & 11.73 & 0.15 & 0.12 & 0.15 & 0.016 \\
\hline
\end{tabular}


Table II. Rolling schedules

Tabla II. Plan de Laminado

Hot Rolling Laminado en Caliente

\begin{tabular}{ccccc}
\hline Pass & $\begin{array}{c}\mathbf{h}_{\mathbf{o}} \\
(\mathbf{m m})\end{array}$ & $\begin{array}{c}\mathbf{h}_{\mathbf{f}} \\
(\mathbf{m m})\end{array}$ & $\begin{array}{c}\mathbf{T} \\
\left({ }^{\circ} \mathbf{C}\right)\end{array}$ & $\begin{array}{c}\text { Reduction } \\
(\%)\end{array}$ \\
\hline 1 & 25.4 & 16.0 & 1.160 & 37 \\
2 & 16.0 & 10.1 & 1.075 & 60 \\
3 & 10.1 & 6.35 & 980 & 75 \\
\hline
\end{tabular}

Cold Rolling

Laminado en Frío

\begin{tabular}{cccc}
\hline Pass & $\mathbf{h}_{\mathbf{o}} \mathbf{( \mathbf { m m } )}$ & $\mathbf{h}_{\mathbf{f}}(\mathbf{m m})$ & Reduction $(\%)$ \\
\hline 1 & 6.1 & 4.3 & 30 \\
2 & 4.3 & 3.1 & 50 \\
3 & 3.1 & 2.0 & 67 \\
4 & 2.0 & 1.5 & 75 \\
5 & 1.5 & 1.12 & 81 \\
\hline
\end{tabular}

transducer to obtain the orientation by EBSD. It is known that frictional forces at the metal and workrolls interface affect the texture at the surface, which differs from that at the bulk of the sample. Hence, specimens of $25 \mathrm{~mm}$ by $20 \mathrm{~mm}$ by the thickness of the strip were polished by mechanical means until mid-thickness was reached; texture analyses were carried out on this surface.

A hydraulic machine was used for tension testing. The samples were an ASTM E8 standard (gage length $25.4 \mathrm{~mm}$, width $6.25 \mathrm{~mm}$, thickness $1.12 \mathrm{~mm}$, length of reduced section $31.65 \mathrm{~mm}$, radius of fillet $6.25 \mathrm{~mm}$, overall length $101.4 \mathrm{~mm}$ ) that were cut in directions parallel, perpendicular and $45^{\circ}$ to the rolling direction. It was not possible to make duplicated tests due to the small amount of material available.

Mechanical properties such as yield strength (YP), ultimate tensile strength (UTS) and elongation (e \%) were obtained by tension testing using samples parallel to the rolling direction. Normal anisotropy ( $r$-value) and planar anisotropy $(\Delta r)$ were obtained by means of:

$$
r_{m}=\left(r_{0}+2 r_{45}+r_{90}\right) / 4
$$

and

$$
\Delta r=\left(r_{0}-2 r_{45}+r_{90}\right) / 2
$$

Where $\mathbf{r}$ is given by the ration of strain along the width direction $\left(\varepsilon_{\omega}\right)$ to that along the thickness direction $\left(\varepsilon_{\tau}\right)$, after tensile deformation of about 15 percent, the subindex refers to the tests conducted on samples cut at 0,45 and $90^{\circ}$ with respect to the rolling direction

\section{RESULTS AND DISCUSSION}

Cold rolled steel samples were annealed at different temperatures for $105 \mathrm{~s}$, as this is the standard time used in continuous annealing ${ }^{[11]}$. Figure 1 shows the microhardness variation as a function of the annealing temperature. No recrystallization occurs below $600^{\circ} \mathrm{C}$, as the hardness remains constant, but between 600 and $750^{\circ} \mathrm{C}$ the hardness decreases, which can be attributed to recovery. Recrystallization starts at $800^{\circ} \mathrm{C}$, when a maximum drop in hardness is achieved. An increase in hardness at $900{ }^{\circ} \mathrm{C}$ was detected. This phenomenon is originated as the alloy reaches the two-phase region caused by the gamma loop region of the $\mathrm{Fe}-\mathrm{Cr}$ phase diagram, (Fig. 2) ${ }^{[12]}$. At this temperature austenite will be formed and will transform into martensite along ferrite grain boundaries during cooling. Two phases were identified by means of Vickers's microhardness indentation, which were ferrite and martensite. The figure $3 \mathrm{a}$ ) shows a sample of microstructure obtained at $900^{\circ} \mathrm{C}$. It can see incipient martensite in grain boundaries. Figure $3 \mathrm{~b}$ ) shows a micro indentation in a martensite zone. Results of the micro hardness for the ferrite and martensite zones are $\mathrm{HV}=130$ and $\mathrm{HV}=270$

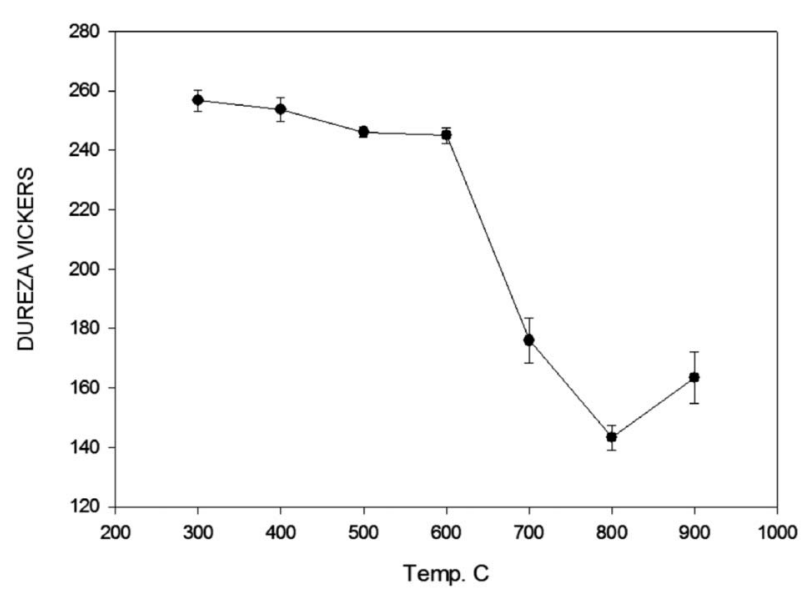

Figure 1. Annealing heat treatment at different temperatures for $105 \mathrm{~s}$.

Figura 1. Tratamiento térmico de recocido a diferentes temperaturas por $105 \mathrm{~s}$. 
ANNEALING OF A FERRITIC STAINLESS STEEL 409 STABILIZED WITH TITANIUM AND ZIRCONIUM ADDITIONS RECOCIDO DE UNA ALEACIÓN DE ACERO INOXIDABLE FERRÍTICO 409 ESTABILIZADO CON ADICIONES DE TITANIO Y ZIRCONIO

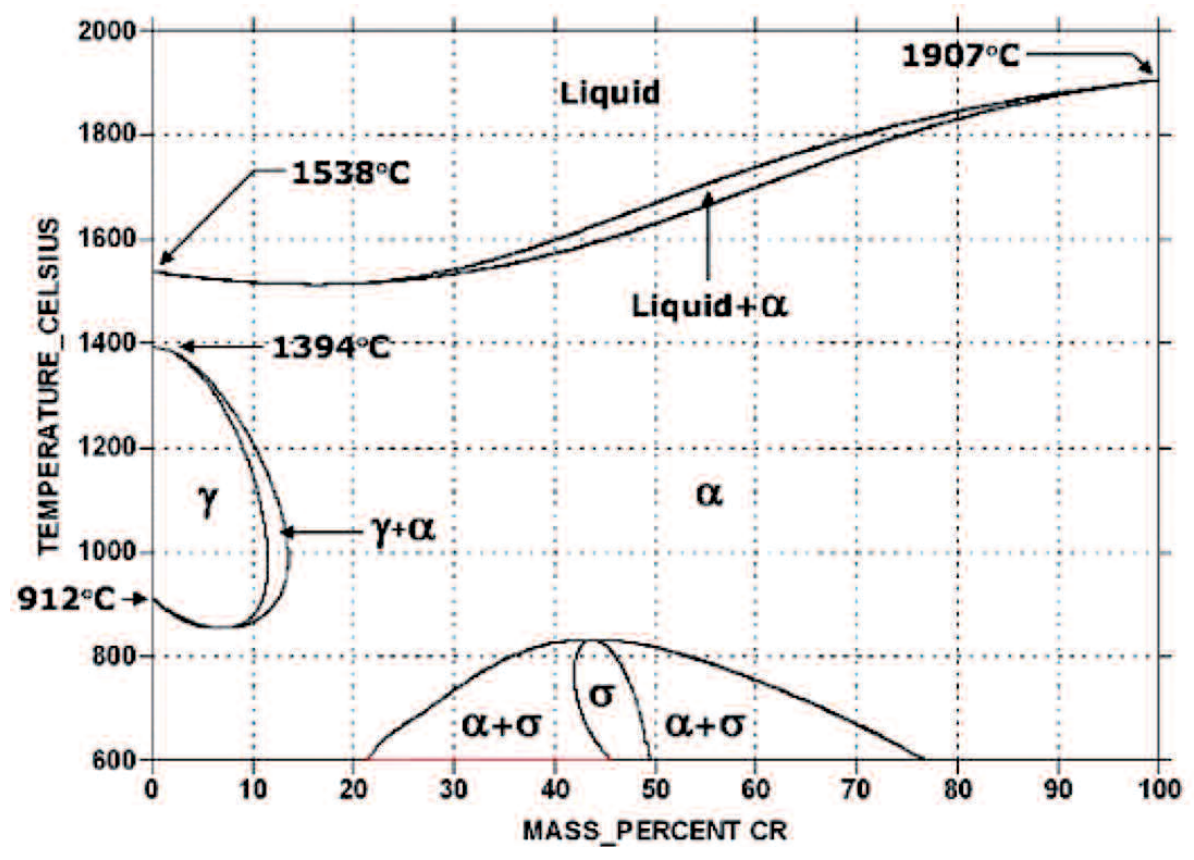

Figure 2. Cr-Fe phase diagram.

Figura 2. Diagrama de fases Cr-Fe.
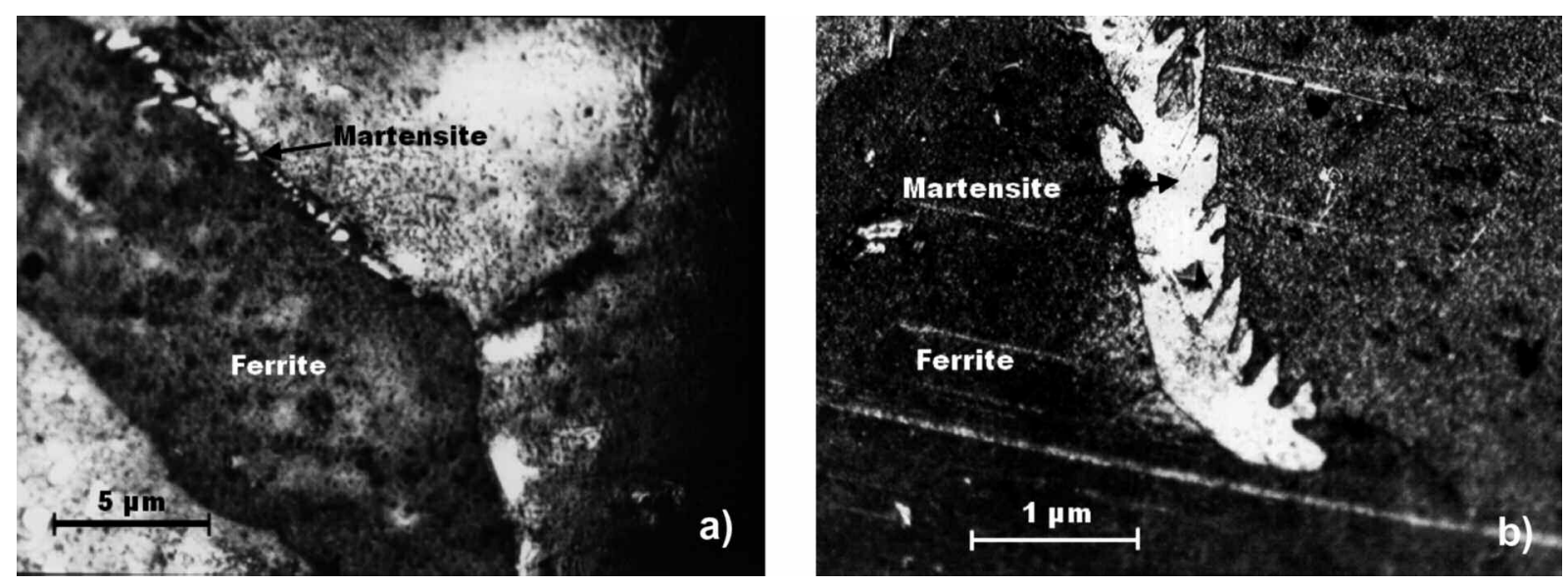

Figure 3. Microestructure of alloy annealed at $900{ }^{\circ} \mathrm{C}$ during $1.45 \mathrm{~min}(105 \mathrm{~s})$ : a) incipient martensite in grain boundaries, b) micro hardness indentation into a martensite zone.

Figura 3. Microestructura de la aleación recocida a $900{ }^{\circ} \mathrm{C}$ durante 1,45 min (105 s): a) inicio de formación de martensita en las fronteras de grano, b) Indentación de microdureza dentro

respectively. It is worth mentioning that the gamma loops varies according to the chemical composition, however for the current case it could be neglected. Changes in microstructure as function of annealing temperature are presented in figure 4 . The early stages of recrystallization at $700^{\circ} \mathrm{C}$ can be observed.

The steel after annealing at $800^{\circ} \mathrm{C}$ for $105 \mathrm{~s}$ shows a microstructure with a large aspect ratio, which is defined as the ratio between the grain size measured on the longitudinal direction over the size measured along the transversal one (Table III). This ratio is related to the degree of recrystallization. Therefore, it was necessary to perform additional annealing treatments for longer times.

The alloy showed improved behavior when it was annealed for 14 min at 800,850 , and $900^{\circ} \mathrm{C}$. Grain 


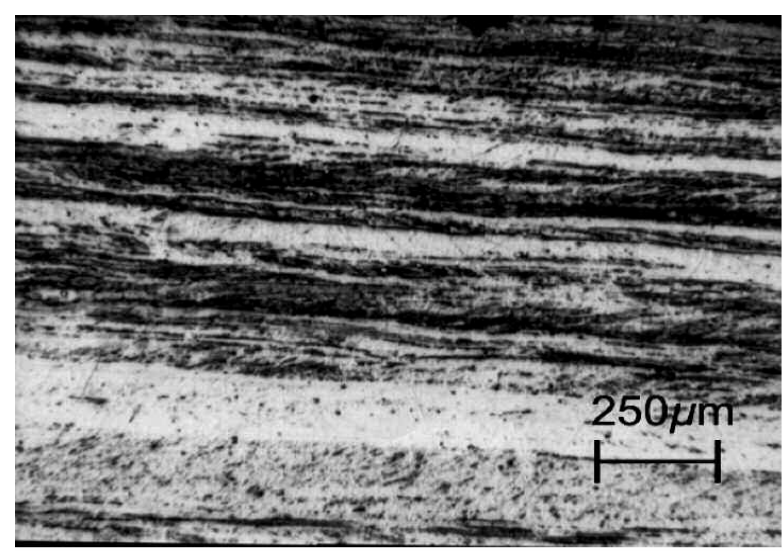

a) $600{ }^{\circ} \mathrm{C}$

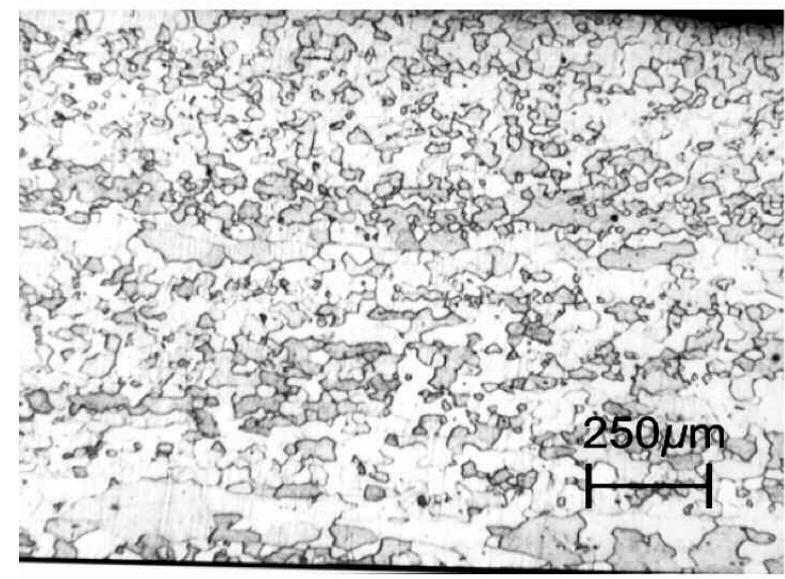

c) $800^{\circ} \mathrm{C}$

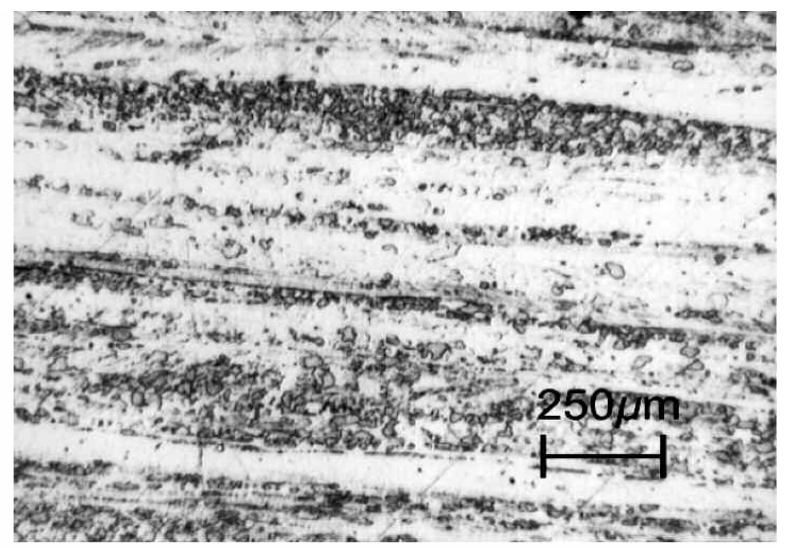

b) $700{ }^{\circ} \mathrm{C}$

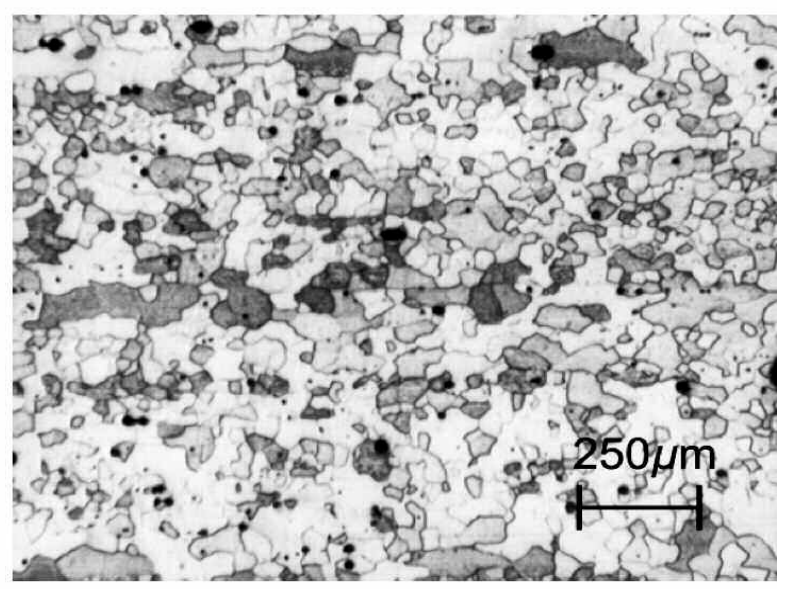

d) $900{ }^{\circ} \mathrm{C}$

Figure 4. Microstructures of alloy at different temperatures of annealing during105 s $(\rightarrow$ Rolling Direction).

Figura 4. Microestructura de la aleación a diferentes temperaturas de recocido durante $105 \mathrm{~s}$ $(\rightarrow$ Dirección del laminado).

Table III. Average size (d) and aspect ratio after annealing for $105 \mathrm{~s}$ at 800 and $900^{\circ} \mathrm{C}$

Tabla III. Tamaño de grano (d) y razón de aspecto después del recocido por $105 \mathrm{~s}$ a 800 y $900{ }^{\circ} \mathrm{C}$

\begin{tabular}{cccc}
\hline $800{ }^{\circ} \mathbf{C}$ & $900{ }^{\circ} \mathbf{C}$ & \\
\hline$d(\mu \mathrm{m})$ & Aspect. ratio & $d(\mu \mathrm{m})$ & Aspect. ratio \\
$17.6 \pm 13.1$ & $1.62 \pm 0.7$ & $18.1 \pm 9.6$ & $1.44 \pm 0.5$
\end{tabular}

size increased marginally with temperature (Table IV), showing a smaller standard deviation than when the samples were annealed for $105 \mathrm{~s}$, and smaller aspect ratio. These observations may be indicative that the alloy achieved complete recrystallization.
It can be considered that an alloy is fully recrystallized when almost the grains boundaries have a misorientation angle higher than $15^{\circ}$, which means that the grains are in their stable state. If the alloy is kept at a high temperature for longer times, the grain size will increase, a process that has been called abnormal grain growth or secondary recrystallization ${ }^{[13 \text { and } 14]}$. Care was taken to avoid this problem, as there was not time enough for such a phenomenon to take place, as the metallographic results indicate that the changes in grain size are kept within a small range.

When two grains have a misorientaion angle less than $15^{\circ}$, they can be in an unstable state, and are known as subgrains, with time and temperature; they will recrystallize by subgrain rotation and coalescence mechanisms.

An effective method of evaluating the degree of recrystallization in a given sample is to calculate the 
ANNEALING OF A FERRITIC STAINLESS STEEL 409 STABILIZED WITH TITANIUM AND ZIRCONIUM ADDITIONS RECOCIDO DE UNA ALEACIÓN DE ACERO INOXIDABLE FERRÍTICO 409 ESTABILIZADO CON ADICIONES DE TITANIO Y ZIRCONIO

Table IV. Average size (d) and aspect ratio after annealing for $14 \mathrm{~min}$ (840 s) at 800,850 and $900{ }^{\circ} \mathrm{C}$

Tabla IV. Tamaño de grano (d) y razón de aspecto después del recocido por $14 \mathrm{~min}(840 \mathrm{~s})$ a 800,850 y $900{ }^{\circ} \mathrm{C}$

\begin{tabular}{cccccc}
\hline $\mathbf{8 0 0}{ }^{\circ} \mathbf{C}$ & & $\mathbf{8 5 0}{ }^{\circ} \mathbf{C}$ & \multicolumn{3}{c}{$\mathbf{9 0 0}{ }^{\circ} \mathbf{C}$} \\
\hline$d(\mu \mathrm{m})$ & Aspect. ratio & $d(\mu \mathrm{m})$ & Aspect. ratio & $d(\mu \mathrm{m})$ & Aspect. ratio \\
$15.31 \pm 6.81$ & $1.21 \pm 0.04$ & $15.81 \pm 5.15$ & $1.28 \pm 0.02$ & $16.64 \pm 5.84$ & $1.05 \pm 0.01$ \\
\hline
\end{tabular}

volume fraction of recrystallized grains. There is an ideal grain boundary distribution whose frequency is random ${ }^{[15]}$. As the area fraction of grain boundary misorientation approaches the normal distribution, the volume fraction of recrystallized grains increases. Full recrystallization is achieved when both distributions are similar.

Figure 5 shows the area fraction of recrystallized grains annealed at $900{ }^{\circ} \mathrm{C}$ for different times versus random distribution. It shows that, with increasing time, the fraction area moves toward grain boundaries with higher misorentation, approaching a random distribution, which means that recrystallization increases with time. Table $\mathrm{V}$ shows the percentage of area fraction for the curves showed in figure 5 . The

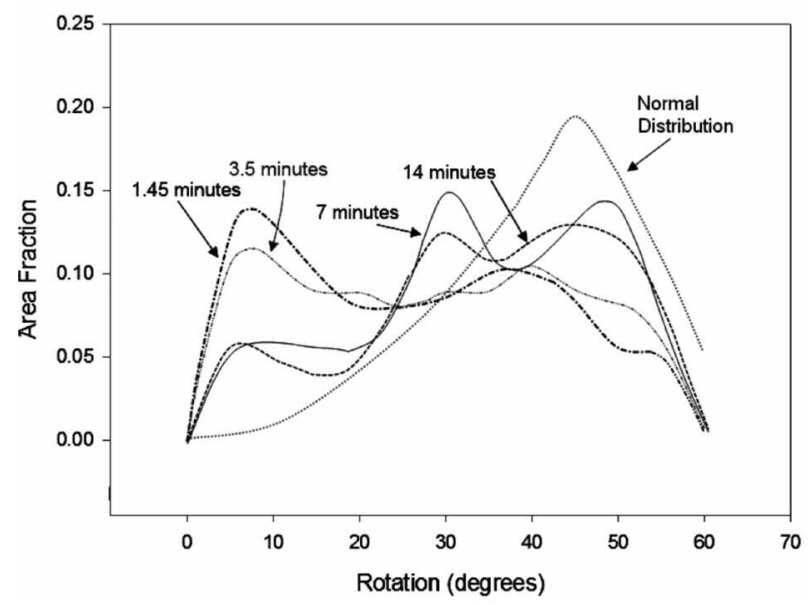

Figure 5. Comparison of the intensity of the grain boundary misorientation area fraction as function of constant temperature of $900{ }^{\circ} \mathrm{C}$ at different annealing times.

Figura 5. Comparación de la intensidad de la fracción de área de la desorientación de las fronteras de grano como función de temperatura constante a $900{ }^{\circ} \mathrm{C}$ para diferentes tiempos de recocido.
Table V. Area fraction of grain boundary misorientation of samples annealed at $900{ }^{\circ} \mathrm{C}$ and different times

Tabla V. Fracción de área de la desorientación de las fronteras de granos de muestra recocidas a $900{ }^{\circ} \mathrm{C}$ y diferentes tiempos

\begin{tabular}{cc}
\hline Time $(\min )$ & \% Area fraction \\
\hline 1.45 & 61.9 \\
3.5 & 66.4 \\
7 & 79.7 \\
14 & 80.6 \\
\hline
\end{tabular}

condition of the highest recrystallization at $900{ }^{\circ} \mathrm{C}$ was found at a $14 \mathrm{~min}$ period.

Since the annealing at 14 min showed the optimum results, other tests were performed at different temperatures in order to find a higher recrystallization.

Figure 6 shows the area fraction of samples annealed for $14 \mathrm{~min}$ at different temperatures versus random distribution. It can be seen that the behavior between temperatures of 800 and $900{ }^{\circ} \mathrm{C}$ is almost the same, although, the results are better for $850^{\circ} \mathrm{C}$. Table VI shows the percentage of area fraction for the curves showed in figure 6 . The alloy at $850^{\circ} \mathrm{C}$ and at a period of 14 min time showed the best recrystallization.

Figures 7 and 8 (corresponding to $\{100\}$ and $\{111\}$ planes) show pole figures obtained from samples annealed at different temperatures for constant holding time $(14 \mathrm{~min})$. This test proves that at $850^{\circ} \mathrm{C}$ the alloy has a very good fiber texture.

Figure 9 shows an ODF section at $\phi 2=45^{\circ}$, Bunge notation, of the material annealed for $14 \mathrm{~min}$ at different temperatures. The diagrams indicate an improved gamma fiber texture in the samples annealed at $850^{\circ} \mathrm{C}$ (Fig. 9 b)). 
Table VI. Area fraction of grain boundary misorientation of samples annealed for $14 \mathrm{~min}$ at different temperatures

Tabla VI. Fracción de área de la desorientación de las fronteras de granos de muestra recocidas por 14 min a diferentes temperaturas

\begin{tabular}{cc}
\hline Temperature ${ }^{\circ} \mathrm{C}$ & \% Area fraction \\
\hline 800 & 77.1 \\
850 & 85.0 \\
900 & 80.6 \\
\hline
\end{tabular}

ASTM specifications (A 240) ${ }^{[16]}$, for ferritic stainless steels 409 indicate that their minimum mechanical properties must be $205 \mathrm{MPa}$ for yield stress, $380 \mathrm{MPa}$ for ultimate tension stress, and $20 \%$ of total elongation.

A major portion of ferritic stainless steel production is cold rolled into sheet. A very substantial

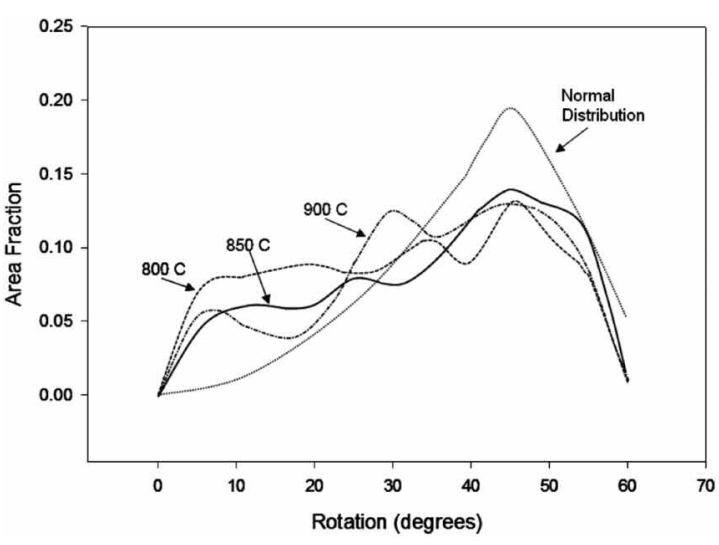

Figure 6. Comparison of the intensity of the grain boundary misorientation area fraction as function of different annealing temperature at constant time of $14 \mathrm{~min}(840 \mathrm{~s})$.

Figura 6. Comparación de la intensidad de la fracción de área de la desorientación de las fronteras de grano en función de diferentes temperaturas de recocido a un tiempo constante de $14 \min (840 \mathrm{~s})$.
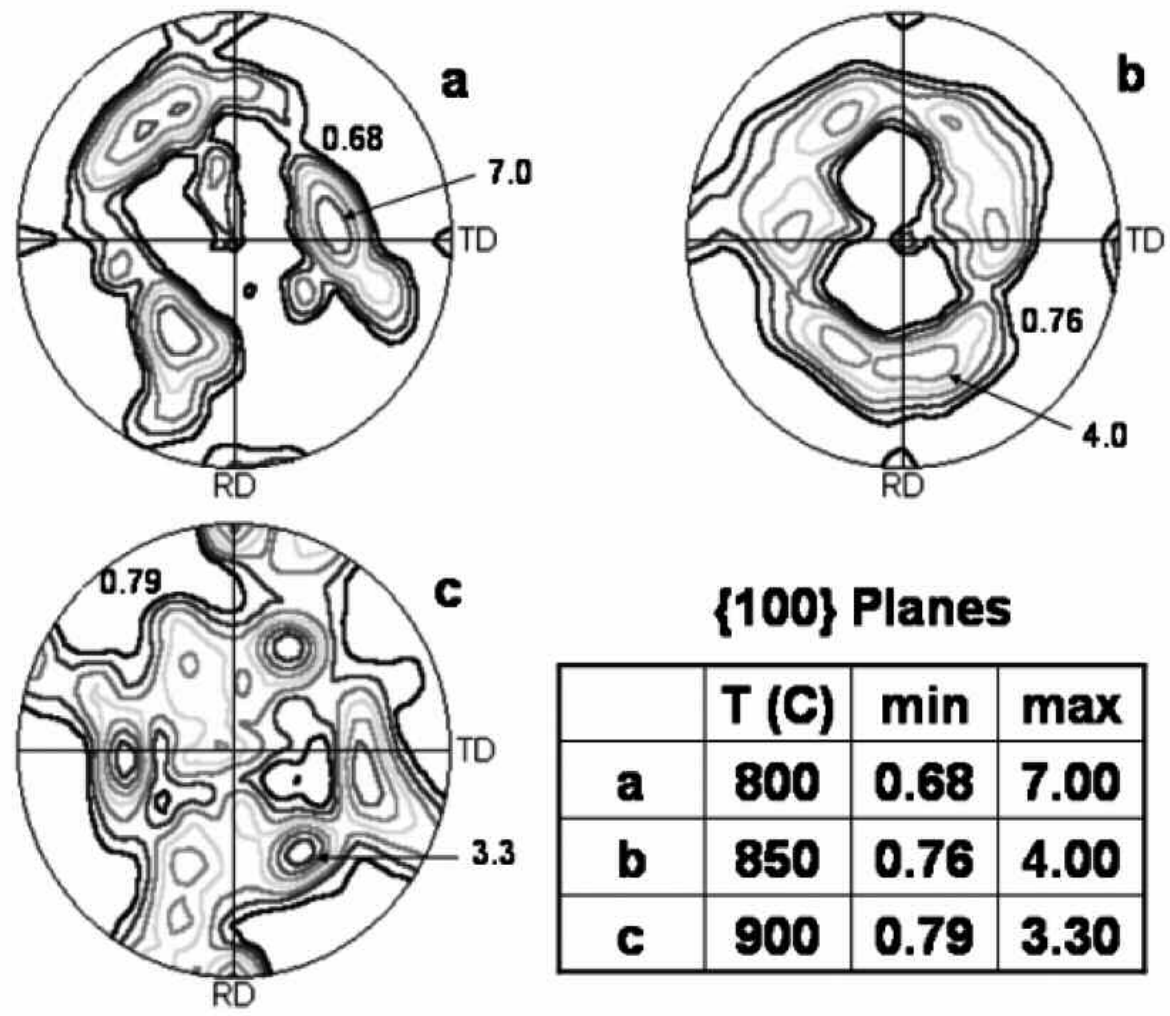

\{100\} Planes

\begin{tabular}{|c|c|c|c|}
\hline & $T(C)$ & $\min$ & $\max$ \\
\hline a & 800 & 0.68 & 7.00 \\
\hline b & 850 & 0.76 & 4.00 \\
\hline c & 900 & 0.79 & 3.30 \\
\hline
\end{tabular}

Figure 7. Resulting pole figures for alloy after annealing at different temperatures at constant holding time $14 \min (840 \mathrm{~s})\{100\}$.

Figura 7. Resultados de la figura de polos para la aleación después del recocido a diferentes temperaturas a tiempo constante de $14 \mathrm{~min}$ (840 s) $\{100\}$. 


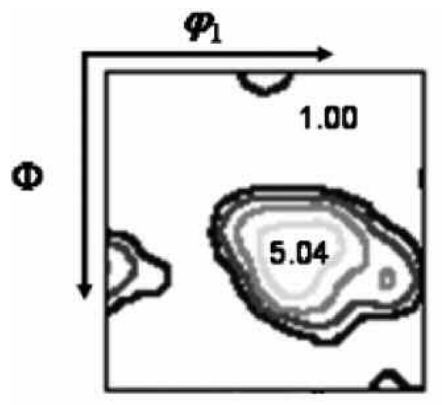

a

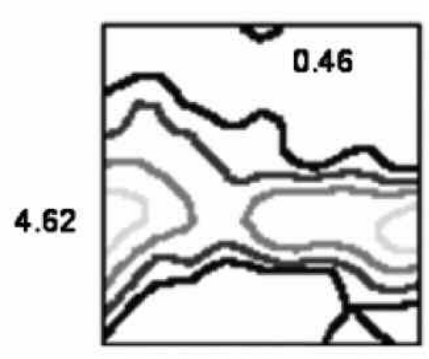

b

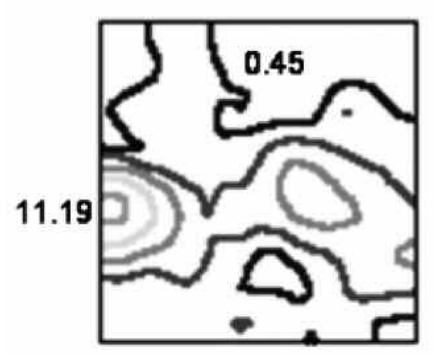

C

$$
\varphi_{2}=4^{\circ}
$$

\begin{tabular}{|c|c|c|c|}
\hline & $T(C)$ & $\min$ & $\max$ \\
\hline a & $\mathbf{8 0 0}$ & 1.00 & 5.04 \\
\hline b & 850 & 0.46 & 4.62 \\
\hline c & 900 & 0.45 & 11.19 \\
\hline
\end{tabular}

Figure 8. Resulting pole figures for alloy after annealing at different temperatures at constant holding time $14 \min (840 \mathrm{~s})\{111\}$.

Figura 8. Resultados de la figura de polos para la aleación después del recocido a diferentes temperaturas a tiempo constante de $14 \mathrm{~min}$ (840 s) $\{111\}$.
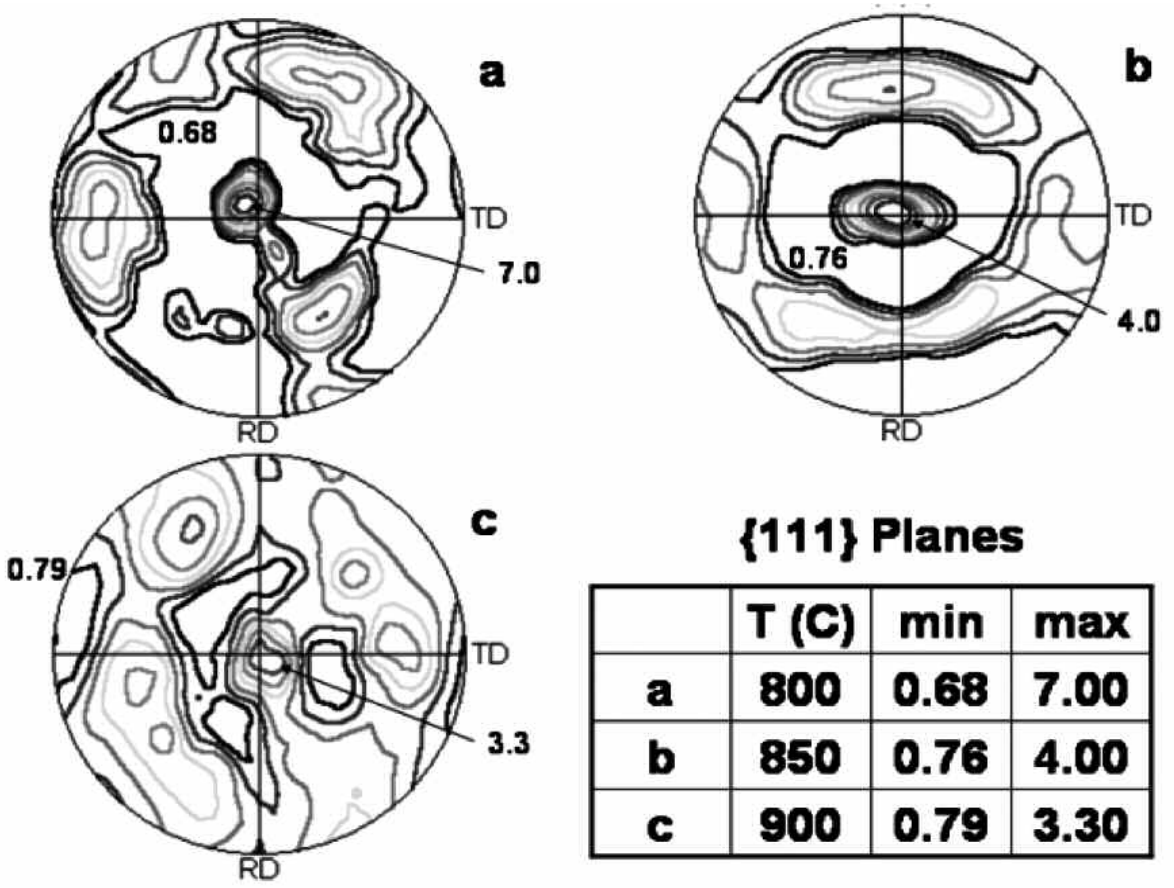

\{111\} Planes

\begin{tabular}{|c|c|c|c|}
\hline & $\mathbf{T}(\mathbf{C})$ & $\min$ & $\max$ \\
\hline a & $\mathbf{8 0 0}$ & 0.68 & 7.00 \\
\hline b & 850 & 0.76 & 4.00 \\
\hline c & 900 & 0.79 & 3.30 \\
\hline
\end{tabular}

Figure 9. ODF section at $\phi 2=45^{\circ}$ of alloy annealing for $14 \mathrm{~min}(840 \mathrm{~s})$, at different temperatures.

Figura 9. Sección de ODF a $\phi 2=45^{\circ}$ de la aleación recocida a $14 \mathrm{~min}$ (840 s) a diferentes temperaturas. 
portion of this sheet is subsequently formed by deep drawing or stretch forming and thus good sheet formability is a very important property of ferritic stainless steels.

The mechanical properties of 409 ferritic stainless steel that support good sheet formability are low yield stress (YP), low ultimate tensile stress (UTS), high percent elongation ( $\mathrm{e} \%)$, normal anisotropy ( $\mathrm{r}$-value) greater than 1.5, and planar anisotropy (Dr) equal to zero $^{[17]}$.

Table VII presents the results of the mechanical properties of the samples investigated. Comparing the current results against the values obtained from the annealing standard, it has been noted that the mechanical properties (i.e. YS, UTS and e\%) present similarities among all temperatures used during test. Nevertheless, it is important to find out among other properties such as anisotropy $\left(\mathbf{r}_{\mathrm{m}}\right)$ and texture, which can be the key properties influencing the improvement of the formability process (i.e. drawability or stretching).

Based on the current results the optimal formability properties were achieved after a $14 \mathrm{~min}$ period of annealing at $850^{\circ} \mathrm{C}$. It is due to its high value of planar anisotropy (Table VII) and also a high intensity ratio $\{111\} /\{100\}$ and a strong fiber texture (Fig. 9 b)). Table VIII shows the texture influence on the $r_{m}$ values. The higher the intensity, the higher the $r_{m}$ values, it has been also reported in the case of other steels ${ }^{[18]}$.

\section{CONCLUSIONS}

- The best annealing cycle for the stabilized ferritic stainless steel 409 with zirconium and titanium

Table VII. Mechanical properties after cold rolling and annealing for $14 \mathrm{~min}$ at different temperatures

Tabla VII. Propiedades mecánicas después del laminado en frío y recocido por $14 \mathrm{~min}$ (840 s) a diferentes temperaturas

\begin{tabular}{cccc}
\hline & $\mathbf{8 0 0}{ }^{\circ} \mathbf{C}$ & $\mathbf{8 5 0}^{\circ} \mathbf{C}$ & $\mathbf{9 0 0}^{\circ} \mathbf{C}$ \\
\hline YP (MPa) & 260 & 270 & 235 \\
UTS(MPa) & 405 & 396 & 375 \\
HV & 134 & 146 & 123 \\
$\%$ e & 41 & 38 & 36 \\
$r_{m}$ & 1.22 & 1.94 & 1.2 \\
$\Delta r$ & 0.82 & 0.89 & 0.1 \\
\hline
\end{tabular}

Table VIII. Texture and $r_{m}$ values

Tabla VIII. Valores de Textura y $r_{m}$

\begin{tabular}{crrc}
\hline Planes & $\mathbf{8 0 0}{ }^{\circ} \mathbf{C}$ & $\mathbf{8 5 0}{ }^{\circ} \mathbf{C}$ & $\mathbf{9 0 0}{ }^{\circ} \mathbf{C}$ \\
\hline$\{111\} /\{100\}$ & 1.48 & 2.41 & 1.25 \\
$r_{m}$ & 1.22 & 1.94 & 1.2 \\
\hline
\end{tabular}

additions understudy was of $850^{\circ} \mathrm{C}$ during 14 min. It is due to its high values of $\mathbf{r}_{\mathrm{m}}$ and texture obtained.

- This annealing cycle allows the formation of a strong fiber texture which enhances the formability of the steel.

- The mechanical properties such as YS, UTS and $\mathrm{e} \%$ present similar values in a range of 800 to $900^{\circ} \mathrm{C}$ for a $14 \mathrm{~min}$ period. These values achieve the annealing standard.

\section{Acknowledgements}

The authors acknowledge the advisory support provided by Professors I. C. Garcia and Q. J. DeArdo from University of Pittsburgh, and the financial support from Universidad Autónoma de Nuevo León, Paicyt and CONACYT.

\section{REFERENCES}

[1] M. Hua, C.I. Garcia, and A.J. DeArdo, ISS $38^{\text {th }}$ Mechanical Working and Steel Processing Conference, Cleveland, EE.UU.,1997, pp. 41-44.

[2] Y. Inove and M. Kikucki, Nippon Steel Thecnical Report, Japan, № 88, July 2003, pp. 61-69.

[3] J. Rege, M.S.Thesis, Materials Science and Engineering, University of Pittsburgh, 1993.

[4] Y. Xu, C.I. Garcia, I. Franson, and A.J. DeArdo, International Symposium. On Low Carbon Steels for the 90's, R. Asfahani and G. Tither (Eds.) TMS, Warrendale, PA, 1993, pp. 397-404.

[5] S. D. Washko, and J.L. Grubb, Proceedings of International Conference on Stainless Steels, ISIJ, Chiba, Japan, June 10-13, 1991.

[6] J.L. Cavazos, Materials Characterization, Ed. Elsevier, 56 (2006) pp. 96-101.

[7] B.D Cullity, Elements of X-ray Diffraction, Ed. Addison-Wesley, 1977, pp. 295-321. 
[8] I.L. Dillamore and W.T. Roberts, Met. Rev. Madrid 10 (1965) 271-380.

[9] F.A. Underwood, Textures in Metals Sheets, Ed. MacDonald, London, 1961.

[10] D.V.Wilson, Met. Rev. Madrid 139 (1969) 175-188.

[11] J. Rege, PhD Thesis Doctoral, University of Pittsburgh, EE.UU. 1998.

[12] E.C. Bain, and R.H. A. Chromium, Iron Phase Diagram, Metals Handbook, American Society for Metals, Metals Park, Ohio, EE.UU. 1948, p. 1194.

[13] J.J. Jonas and L. Kestens, Proc. of $1^{\text {st }}$ Joint Int. Conf. on Recrystallization and Grain Growth, Ed. by G. Gottstein and D. A. Molodov, Springer-Verlag, Berlin, 2001, pp. 49-60.
[14] R.W. Cahn, Physical Metallurgy, 4 Edition, R.W. Cahn and P. Haasen (Eds.), Amsterdam, North Holland, 1996, pp. 2399-2500.

[15] J.K. Mackenzie: Biometrika, 45 (1958) p. 229.

[16] ASTM A 240/A 240M Standard Specification for Chromium and Chromium-Nickel Stainless Steel Plate, Sheet, and Strip for Pressure Vessels and for General Applications, 2009, pp. 9-13.

[17] ASM Handbook Volume 1, Tenth Edition, Rudolf Steiner and American Society for Metals, ASM International, Ohio, EE.UU., 1990, pp. 1330-1332.

[18] D. Raabe and K. Luucke, Textures of ferritic stainless steels, Materials Science and Thechnology, Ed. Maney Publishing, Vol. 9, 1993, pp. 302-312. 